\title{
Essential Oil Activity Against Methicillin-Resistant Staphylococcus aureus and Multidrug-Resistant Mycobacterium tuberculosis: A Mini-Review
}

\author{
Azeem Intisar*, Aqsa Aamir and Kalsoom Kausar \\ Institute of Chemistry, University of the Punjab, Pakistan
}

Submission: January 24, 2020; Published: February 18, 2020

"Corresponding author: Azeem Intisar, Institute of Chemistry, University of the Punjab, Lahore, Pakistan

\begin{abstract}
Drug resistance among pathogenic bacteria has been a major concern for decades. Diseases caused by them have been the main cause of death in developing countries where this factor contributes around one third of the total number of deaths. With the gradual increase in microbial resistance and the side effects that synthetic medicines may cause, there has always been a need of finding natural medicines that can effectively treat such diseases. Among such potent resources are plant essential oils that have been reported in literature and is a recent topic of extraordinary interest. In this study, antimicrobial potential of essential oils of various plants against two resistant strains: methicillin-resistant Staphylococcus aureus (MRSA) and multidrug-resistant Mycobacterium tuberculosis (MDRTB), has been discussed.
\end{abstract}

Keywords: Essential Oils; MRSA; M. Tuberculosis; Antibacterial Activity; Drug-Resistant Microbes

\section{Introduction}

In present situation, where drug-resistant bacteria are widely spread, lesser options are available due to decreased number of novel drugs being manufactured. Generally known examples of such microbes are Methicillin-resistant Staphylococcus aureus, multidrug-resistant Mycobacterium tuberculosis vancomycinresistant enterococci, and penicillin-resistant Neisseria gonorrhoeae etc. The situation is getting worse due to the origination of prevalent, MDR Stenotrophomonas maltophilia and Burkholderia cepacia [1,2].

In 1940 s, penicillin was used to cure the infections caused by S. aureus. Subsequently, penicillin resistant S. aureus developed and spread all over the world due to the increased usage of penicillin. In 1960s, methicillin was prepared to cope up with penicillin-resistant S. aureus and widely used in US and Europe, but bacteria quickly developed the resistance against methicillin. This led to the conclusion that various antibiotics may no longer be used to treat the diseases caused by such bacteria, and threat of using other drugs is gradually increasing. Thus, several new antibiotics have been prepared for the treatment of drug resistant bacteria up to 5 th generation where cephalosporin is a promising entity [3-5].
MRSA possesses specific threats to elderly or postsurgical patients. It is a resident microbe, which is innocuous for healthy individuals, but obstinate in immunosuppressed patients, and is found in organ abscesses, infectious endocarditis, bone infection (osteomyelitis) and post-operative wound infection [4]. Another drug resistant bacterium includes Mycobacterium tuberculosis that causes Tuberculosis (TB), a major cause of death since long with around 1.7 million deaths in 2006 [6]. TB control is challenging due to the development of MDR and XDR (extensively drug resistant) strains [7]. After the use of anti-TB drugs in 1940s, issue of drug resistance was reported among the patients receiving the treatment [8].

Drug resistance of this strain was continuously increasing all over the world which resulted in explosive emergence of MDRTB in early 1990s which was resistant to the two most effective first line anti-TB agents, isoniazid and rifampicin. Later on, 45 countries reported the cases of XDR-TB which was not only resistant to isoniazid and rifampicin but also to at least one of the fluoroquinolones and to any of the second line drugs which include capreomycin, amikacin and kanamycin $[9,10]$. cepacia Among the potent 
natural resources are plant essential oils that have been reported in literature and became a recent topic of extraordinary interest. In this study, an overview of the effect of essential oils on MRSA and MDRTB has been presented.

\section{Discussion}

Essential oils that strongly inhibit MRSA include melissa, cinnamon, mountain savory, lemon myrtle and lemongrass. Several essential oils exhibit inhibitory activity against MRSA, when used in a combination and include Eucalyptus citriodora, peppermint, spruce, cypress, lavender, pine, myrtle, marjoram, Eucalyptus radiata, Eucalyptus australiana and Eucalyptus globulus oils. "Motivation", a combination of lavender, spruce, ylang ylang and Roman chamomile oils and "Longevity", a combination of thyme, orange, clove and frankincense oils, showed the maximum inhibitory activity [11].

These MDR strains were also inhibited by essential oils of Eucalyptus globulus and Thymus vulgaris with MIC values of 85.6 $(\mu \mathrm{g} / \mathrm{mL})$ and $18.5(\mu \mathrm{g} / \mathrm{mL})$ against MRSA respectively [11,12]. Strong inhibitory activity was observed by the essential oils of Clerodendrum serratum against MRSA whereas fruit oil of a common Sub-continent tree, Terminalia arjuna exhibited an MIC 0.16 $\mathrm{mg} / \mathrm{mL}$ against MRSA $[13,14]$. Several other plants have been checked for their antibacterial potential against MRSA among which the most active essential oils include Cinnamomum verum, Satureja montana, Origanum heracleoticum, Cinnamomum cassia and Corydothymus capitatus. They showed an MIC $\leq 0.05 \%(\mathrm{v} / \mathrm{v})$ for this strain [15].

The essential oil of M. communis exhibited promising activity; MIC $0.17 \%(\mathrm{v} / \mathrm{v})$, against all strain types of M. tuberculosis, including XDR strain. $\alpha$-pinene, 1-8 cineole and limonene were tested for their antimicrobial potential against these strains. Limonene was found to be most active exhibiting an MIC value of 2 $\%(\mathrm{v} / \mathrm{v})$ for all strains, followed by $\alpha$-pinene with MIC value of 1-16\% and 1-8 cineole with MIC value, of 2-16\% (v/v). Essential oil activity was compared with 4 antitubercular drugs taken as standard including ethambutol, rifampin, isoniazid and streptomycin. All mycobacterial strains were resistant towards some or all of these drugs including an XDR strain. Screened essential oils showed a better antibacterial potential as compared to each single drug checked against all mycobacteria [16].

Essential oils of several plants were checked for their antimicrobial potential against different resistant variants of M. tuberculosis H37Rv and the significant activity was shown by 0. europaea, N. officinale, C. sinensis and C. aurantifolia [17]. Similarly, essential oils of T. spicata and Origanum minutiflorum showed significant activity against Mycobacterium tuberculosis H37Ra with an MIC value of $196 \mu \mathrm{g} / \mathrm{mL}$ and $392 \mu \mathrm{g} / \mathrm{mL}$ [18]. Essential oils of S. aratocensis, T. diffusa and L. americana showed good activity against various MDR strains of M. tuberculosis with an MIC range of 50$125 \mu \mathrm{g} / \mathrm{mL}$. This data suggests the use of these plants as an im- portant sources of the compounds having antimicrobial potential against MDR M. tuberculosis [19].

Individual compounds such as Terpinolene, $\alpha$-Terpinene, t-Anethole, Sabinene, Myrcene, Menthol, Linalool, (+) Limonene, Geraniol, Eugenol, Eucalyptol, Estragole, Cuminaldehyde, $\beta$-Citronellol, (+) Carvone, $\beta$-Caryophyllene, p-Cymene, 3-Carene, $\beta$-pinene, $\mathrm{p}$-Anisaldehyde, Camphor, Cinnamic Acid etc. were tested and found to be potent against M. tuberculosis. Among terpenes, thymol and carvacrol exhibited the strongest activity with MIC 0.78 and $2.02 \mu \mathrm{g} / \mathrm{mL}$ respectively. Among phenylpropanes cinnamic acid and cinnamaldehyde showed the best activity with MIC 8.16 and $3.12 \mu \mathrm{g} / \mathrm{mL}$ respectively [20]. Although the employment of volatile and essential oils as antimicrobial agents is promising, it still needs more in vivo studies along with clinical trials involving several subjects to increase their reliability [21-23].

\section{Conclusion}

Essential oils may possibly be employed as a potential source in solving the problem of drug resistance. MRSA and MDR M. tuberculosis variants show susceptibility towards essential oils of numerous plants and individual compounds of essential oils. This leads to conclude that essential oils may provide the solution of treating those resistant microbes for which options of existing synthetic drugs are getting limited with the passage of time.

\section{Conflict of Interest}

Authors declare no conflict of interest

\section{References}

1. Cohen S N, A C Chang, L Hsu (1972) Non chromosomal antibiotic resistance in bacteria: genetic transformation of Escherichia coli by R-factor. DNA Proceedings of the National Academy of Sciences 69(8): 2110-2114.

2. Russell A (2002) Antibiotic and biocide resistance in bacteria: introduction. Journal of applied microbiology 92: 1S-3S.

3. Saga T, K Yamaguchi (2009) History of antimicrobial agents and resistant bacteria. JMAJ 52(2): 103-108.

4. Namba K, K Motoshima, H Kobayashi, A Tai, E Takahashi, et al. (2008) Design and synthesis of benzeneesulfonanilides active against methicillin-resistant Staphylococcus aureus and vancomycin-resistant. Enterococcus Bioorganic \& medicinal chemistry 16(11): 6131-6144.

5. Luzzatto L, D Apirion, D Schlessinger (1968) Mechanism of action of streptomycin in E coli: interruption of the ribosome cycle at the initiation of protein synthesis. Proceedings of the National Academy of Sciences of the United States of America 60(3): 873.

6. Organization W H (2008) Global tuberculosis control: surveillance, planning, financing: WHO report Vol 393 2008: World Health Organization.

7. Jain A, R Mondal (2008) Extensively drug-resistant tuberculosis: current challenges and threats FEMS. Immunology \& Medical Microbiology, 53(2): 145-150.

8. Iseman M D (1994) Evolution of drug-resistant tuberculosis: a tale of two species. Proceedings of the National Academy of Sciences 91(7): 2428-2429. 
9. Wright A, M Zignol (2008) Anti-tuberculosis drug resistance in the world: fourth global report: the world health organization/international union against tuberculosis and lung disease (who/union) global project on anti-tuberculosis drug resistance surveillance 2002-2007: World Health Organization.

10. Sandgren A, K Motoshima, H Kobayashi, A Tai, E Takahashi, et al. (2009) Tuberculosis drug resistance mutation database. PLoS medicine 6(2): e1000002.

11. Chao S, G Young, C Oberg, K Nakaoka (2008) Inhibition of methicillinresistant Staphylococcus aureus (MRSA) by essential oils. Flavour and fragrance journal 23(6): 444-449.

12. Tohidpour A, et al. (2010) Antibacterial effect of essential oils from two medicinal plants against Methicillin-resistant Staphylococcus aureus (MRSA). Phytomedicine 17(2): 142-145.

13. Noreen R, et al. (2018) Constituents of Volatile Oil from Bark of Clerodendrum serratum (L) and its Antibacterial Activity. Journal of Essential Oil-Bearing Plants 21(1): 198-205.

14. Bano S, Intisar A, Rauf M, Ghaffar A, Yasmeen F, et al. (2018) Comparative analysis of oil composition and antibacterial activity of aerial parts of Terminalia arjuna (Roxb ). Natural product research 1-4.

15. Oussalah M, Stéphane Caillet, Linda Saucier, Monique Lacroix (2007) Inhibitory effects of selected plant essential oils on the growth of four pathogenic bacteria: E coli 0157: H7, Salmonella typhimurium, Staphylococcus aureus and Listeria monocytogenes. Food control 18(5): 414 420.

16. Zanetti S, Sara Cannas, Paola Molicotti, Alessandra Bua, Marina Cubeddu, et al. (2010) Evaluation of the Antimicrobial Properties of the Essential Oil of Myrtus communis L against Clinical Strains of Mycobacterium spp. Interdisciplinary perspectives on infectious diseases.
17. Camacho Corona M d R, Ramírez Cabrera MA, Santiago OG, Garza González E, Palacios Ide P, et al. (2008) Activity against drug resistanttuberculosis strains of plants used in Mexican traditional medicine to treat tuberculosis and other respiratory diseases. Phytotherapy Research: An International Journal Devoted to Pharmacological and Toxicological Evaluation of Natural Product Derivatives 22(1): 82-85.

18. Askun T, Tumen Gulendam, Satil Fatih, Ates Mustafa (2009) In vitro activity of methanol extracts of plants used as spices against Mycobacterium tuberculosis and other bacteria. Food Chemistry 116(1): 289294.

19. Bueno J, P Esobar, JR Martinez, SM Leal, EE Stashenko (2011) Composition of three essential oils, and their mammalian cell toxicity and antimycobacterial activity against drug resistant-tuberculosis and nontuberculous mycobacteria strains. Natural product communications 6(11): p 1934578X1100601143.

20. Andrade Ochoa S, Guadalupe Virginia Nevárez Moorillón, Luvia E Sánchez Torres, Manuel Villanueva García, Blanca E Sánchez Ramírez, et al. (2015) Quantitative structure-activity relationship of molecules constituent of different essential oils with antimycobacterial activity against Mycobacterium tuberculosis and Mycobacterium bovis. BMC complementary and alternative medicine 15(1): 332.

21. Sherry E, H Boeck, P H Warnke (2001) Topical application of a new formulation of eucalyptus oil phytochemical clears methicillin-resistant Staphylococcus aureus infection. American journal of infection control 29(5): 346.

22. Pauli A, H Schilcher (2004) Specific selection of essential oil compounds for treatment of children's infection diseases. Pharmaceuticals 1(1): 1 .

23. Halcón L, K Milkus (2004) Staphylococcus aureus and wounds: a review of tea tree oil as a promising antimicrobial. American journal of infection control 32(7): 402-408.

\section{Your next submission with Juniper Publishers will reach you the below assets}

- Quality Editorial service

- Swift Peer Review

- Reprints availability

- E-prints Service

- Manuscript Podcast for convenient understanding

- Global attainment for your research

- Manuscript accessibility in different formats

( Pdf, E-pub, Full Text, Audio)

- Unceasing customer service

Track the below URL for one-step submission https://juniperpublishers.com/online-submission.php 